\title{
Planktic Cyanobacteria in the Lower Uruguay River, South America
}

\author{
Graciela Ferrari ${ }^{1 *}$, María del Carmen PéreZ², María Dabezies ${ }^{1}$, Diana Míguez ${ }^{3}$ \& \\ Carlos SAIZAR ${ }^{1}$ \\ ${ }^{1}$ Department of the Environment, Laboratorio Tecnológico del Uruguay (LATU), Avda. Italia 6201, CP 11500 \\ Montevideo,Uruguay; e-mail: gferrari@latu.org.uy,mdabez@latu.org.uy,csaizar@latu.org.uy \\ ${ }^{2}$ Phytoplankton Consultant, Calle Busot 6, 14 46007 Valencia, Spain; e-mail: perez.baliero@gmail.com \\ ${ }^{3}$ Department of Water and Chemicals, Laboratorio Tecnológico del Uruguay (LATU), Avda. Italia 6201, CP \\ 11500. Montevideo,Uruguay; e-mail: dmiguez@latu.org.uy
}

\begin{abstract}
The Uruguay River is the second most important river in the Río de la Plata Basin. Taxonomical composition, abundance and distribution of cyanobacteria collected at nine sampling stations in the Lower Uruguay River (Uruguay) were analyzed seasonally from 2006 to 2009. A total of 24 taxa were identified, including 13 Chroococcales, 4 Oscillatoriales and 7 Nostocales species. The genera Dolichospermum and Microcystis presented the highest number of species among the planktic water bloom-forming cyanobacteria. The highest densities of cyanobacteria were recorded in summer during a bloom, with $6.2 \times 10^{6} \mathrm{cells} . \mathrm{ml}^{-1}$, and the most abundant species were Microcystis aeruginosa and Dolichospermum cf. pseudocompactum. In this case, the toxicity analyses by HPLC did not indicate the presence of microcystin-LR. Phytoplankton growth in the Uruguay River was found not to be nutrient-limited. The high correlation of cyanobacteria densities with nitrogen and phosphorous compounds is directly related to changes in flow. Cyanobacteria densities increased with summer high temperatures in low flow conditions. The ANOSIM analysis showed no significant differences between zones and sampling sites, but there were temporal significant differences in relation to seasonal samplings. Radiocystis fernandoi KомÁREK et Komarkoví-Legnerová was recorded for the first time in Uruguay and Dolichospermum cf. pseudocompactum (WATANABE) WACKLIN et al. was recorded for the first time in South America.
\end{abstract}

Key words: Cyanobacteria, Dolichospermum, Microcystis, monitoring, phytoplankton, Uruguay River

\section{Introduction}

The Uruguay River belongs to the La Plata Basin and stretches over $1,800 \mathrm{~km}$. Its lower part flows between two countries: Argentina and Uruguay. It is one of the largest rivers in South America and ends in the Río de la Plata Estuary. Based on historic values (1983-2003) (ECOMETRIX 2006), the river's average annual discharge is $6230 \mathrm{~m}^{3} \cdot \mathrm{s}^{-1}$. One of the main factors affecting the quality of water is the construction of more than twenty hydropower dams for attending the energy demand of the economic growth in the region. In particular, the Salto Grande Dam, located 300 $\mathrm{Km}$ upstream the river mouth, have an important regulatory effect over the discharges above and within the Río de la Plata Estuary. In recent years, other human activities, such as an increasing urbanization and the expansion of agriculture, together with climate variations, have modified the flow, as well as the quality of the water in the whole basin, resulting in conditions that favor the proliferation of algal blooms (CARMICHAEL 1992; SMAYDA 1997). The occurrence of such blooms is a potential health hazard that jeopardizes the sources of water used as drinking water and for other purposes such as fishing and recreation (ChORUS \& BARTRAM 1999).

Agriculture is an important activity in the Lower Uruguay River Basin with a significant production of citrus fruit and other crops. The most important Uruguayan city in the studied area is Fray Bentos, which is also an active port. The most important industry in the area is the paper mill UPM, devoted to the production of paper pulp since 2007.

The climate of the region is humid subtropical (BAILEY 1998) with a mean annual air temperature ranging between $16^{\circ} \mathrm{C}$ and $17^{\circ} \mathrm{C}$, and 
rainfalls regularly distributed over the year, with an average of $6230 \mathrm{~m}^{3} \cdot \mathrm{s}^{-1}$ (ECOMETRIX 2006).

Several authors have conducted phytoplanktonic studies that include the cyanobacteria in Argentinean and Uruguayan rivers (Bonilla 1997; García De Emiliani 1981, 1990; Gómez \& Bauer 1998; Lacoste De Diaz 1961; O'farrell et al. 1996; OnNa 1978; Pérez et al. 1999; Pérez 2002; Schiaffino 1977; SCHIAfFino 1981; Zalocar De Domitrovic 2005; Zalocar De Domitrovic \& Forastier 2005; Zalocar De Domitrovic et al. 2007). However, the Lower Uruguay River has been scarcely studied (O'FARrell \& IZAGuirRe 1994; Quiros \& LUCHINI 1982), and the Salto Grande Dam was studied only by De León \& Chalar 2003 and Chalar 2009.

In this study we report the composition, density and distribution of cyanobacteria from the Lower Uruguay River. Relations between cyanobacterial blooms and environmental variables in this river were also discussed.

\section{Materials and Methods}

Study area. The studied area comprises three zones along the Lower Uruguay River, which belong to the Department of Río Negro: Nuevo Berlín (NB), Fray Bentos (FB) and Las Cañas (LC). A transect line was drawn perpendicular to the coastline in each zone, between the Uruguayan coast and the river channel, establishing three sampling points: littoral, center and channel (Fig. 1).

Samplings. Twelve seasonal samplings on the Lower Uruguay River were carried out from July 2006 to May 2009 (Table 1). An extra sampling was performed in the summer 2008 (February $4^{\text {th }}$ ) as a result of an alert of algae blooms in the area. Conductivity, temperature and $\mathrm{pH}$ were measured in situ with a YSI 600R and a YSI 6600 V2 sensors and the transparency was estimated with a Secchi disc. Water samples were taken directly for nutrient analyses, in accordance with ISO Standard 5667-3. Phytoplankton samples were taken for qualitative testing using a $20-\mu \mathrm{m}$ mesh plankton net, towing horizontally in the central point of the transect station. Samples were then fixed in situ with $2-3 \%$ formaldehyde. Phytoplankton for quantitative analyses were collected with water bottles at successive extractions from $2 \mathrm{~m}$ depth to surface with a van Dorn bottle, trying to cover an integrated surface water; the samples were fixed with Lugol's solution (SourNIA 1978).

Analyses. Physico-chemical water analyses were performed following relevant standards: Nitrates (ISO

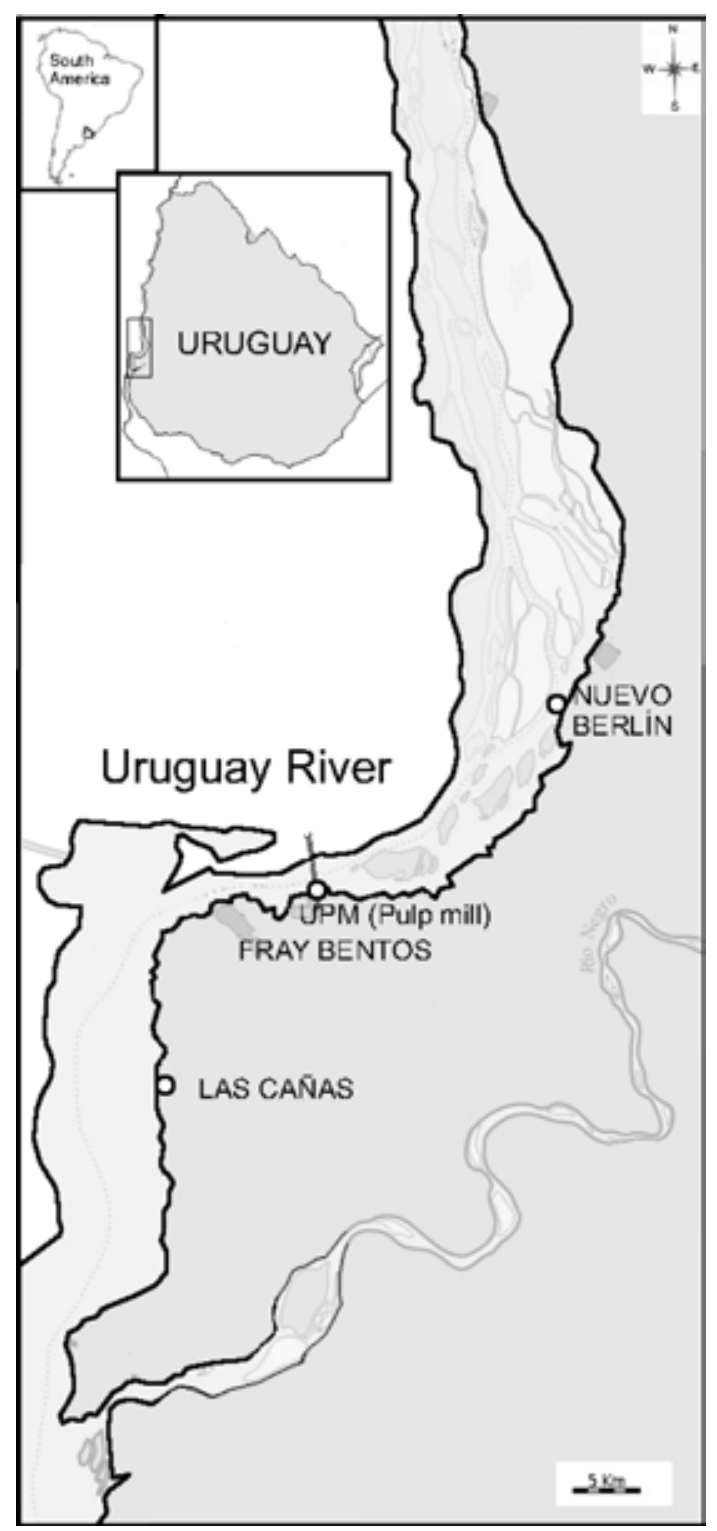

Fig. 1. Study area of the Uruguay River and sampling zones: Nuevo Berlín, Fray Bentos and Las Cañas (black-white circles).

10304 / 1:1992), Nitrites (ISO 6777), ammonium (ISO 6778:1984), total nitrogen (ISO 11905-2, modified detection electrochemical cell), soluble phosphorus (ISO 6878) and Chlorophyll a (ISO 10260:1992).

The taxonomic identification was carried out with light microscopes (Olympus CX41 and Nikon Eclipse E800), using a 1000x magnification. The organisms were measured and photographed with a DXM 1200 digital camera. The counts were performed with an Olympus CKX41 inverted microscope, following the methodology described by UTERMÖHL (1958). Counts included at least 100 cells of the most abundant species, to yield a confidence interval of $95 \%$ with a counting error under $20 \%$ (LUND ET AL. 1958). In the case of Microcystis spp. bloom, the methodology employed followed Box (1981), counting the number of 
Table 1. Average and standard deviations: SDV (italic) of the main parameters recorded in the nine sampling points in the Lower Uruguay River: $\mathrm{NO}_{3}{ }^{-}$Nitrite $\left(\mathrm{mg} .1^{-1}\right)$, Soluble Reactive Phosphorus SRP $\left(\mu \mathrm{g} .1^{-1}\right)$, chlorophyll Chl- $a\left(\mu \mathrm{g} .1^{-1}\right)$, Secchi disk-SD $(\mathrm{cm})$, temperature $\mathrm{T}\left({ }^{\circ} \mathrm{C}\right)$, Conductivity $\mathrm{K}\left(\mu \mathrm{S} . \mathrm{cm}^{-1}\right)$, flow $\mathrm{Q}\left(\mathrm{m}^{3} \cdot \mathrm{s}^{-1}\right)$, euphotic zone $\mathrm{Ez}(\mathrm{cm})$ and $\mathrm{Kd}(\mathrm{m})$.

\begin{tabular}{|c|c|c|c|c|c|c|c|c|c|c|c|}
\hline & & & $\begin{array}{c}\mathrm{NO3} \\
\left(\mathrm{mg} .1^{-1}\right)\end{array}$ & $\begin{array}{c}\text { SRP } \\
\left(\mu \mathrm{g} .1^{-1}\right)\end{array}$ & $\begin{array}{c}\text { Chl a } \\
\left(\mu \mathrm{g} .1^{-1}\right)\end{array}$ & $\begin{array}{l}\text { SD } \\
(\mathrm{cm})\end{array}$ & $\begin{array}{c}\mathrm{T} \\
\left({ }^{\circ} \mathrm{C}\right)\end{array}$ & $\begin{array}{c}\mathrm{K} \\
\left(\mu \mathrm{S} . \mathrm{cm}^{-1}\right)\end{array}$ & $\begin{array}{c}\mathrm{Q} \\
\left(\mathrm{m}^{3} \cdot \mathrm{s}^{-1}\right)\end{array}$ & $\begin{array}{c}\mathrm{Ez} \\
(\mathrm{cm})\end{array}$ & $\begin{array}{l}\mathrm{Kd} \\
(\mathrm{m})\end{array}$ \\
\hline \multirow[t]{4}{*}{2006} & Jul & Mean & 1.11 & 22.68 & 0.63 & 78.33 & 13.8 & 0.339 & 2078 & 188.0 & 2.4 \\
\hline & & $S D V$ & 0.26 & 15.25 & 0.28 & 7.50 & 0.8 & 0.01 & 654 & 18.0 & 0.2 \\
\hline & Oct & Mean & 0.37 & 22.62 & 1.63 & 50.56 & 23.9 & 0.054 & 4514 & 121.3 & 3.9 \\
\hline & & $S D V$ & 0.27 & 15.09 & 0.40 & 10.14 & 0.9 & 0.00 & 1686 & 24.3 & 0.6 \\
\hline \multirow[t]{4}{*}{2007} & $\mathrm{Feb}$ & Mean & 1.22 & 69.49 & 1.09 & 65.00 & 27.8 & 0.059 & 2213 & 156.0 & 3.0 \\
\hline & & $S D V$ & 0.03 & 13.92 & 0.49 & 10.00 & 0.9 & 0.00 & 40 & 24.0 & 0.5 \\
\hline & May & Mean & 1.19 & 58.89 & 0.37 & 47.78 & 20.7 & 0.160 & 5538 & 114.6 & 4.4 \\
\hline & & $S D V$ & 0.16 & 26.71 & 0.10 & 14.81 & 1.6 & 0.23 & 1717 & 35.5 & 1.5 \\
\hline \multirow[t]{4}{*}{2007} & Aug & Mean & 2.59 & 26.56 & 0.40 & 47.78 & 12.2 & 0.070 & 6366 & 114.6 & 4.1 \\
\hline & & $S D V$ & 1.16 & 6.77 & 0.15 & 9.72 & 0.3 & 0.00 & 1184 & 23.3 & 0.8 \\
\hline & Nov & Mean & 0.17 & 49.44 & 0.68 & 48.89 & 21.2 & 0.057 & 8018 & 117.3 & 4.0 \\
\hline & & $S D V$ & 0.50 & 24.22 & 0.33 & 7.82 & 0.5 & 0.00 & 239 & 18.7 & 0.6 \\
\hline \multirow[t]{4}{*}{2008} & $\mathrm{Feb}$ & Mean & 0.06 & 17.37 & 41.55 & 101.11 & 27.9 & 0.067 & 2667 & 242.7 & 1.9 \\
\hline & & $S D V$ & 0.01 & 21.32 & 57.74 & 6.01 & 0.5 & 0.00 & 712 & 14.4 & 0.1 \\
\hline & May & Mean & 0.05 & 4.89 & 11.21 & 150.00 & 18.8 & 0.064 & 4176 & 360.0 & 1.3 \\
\hline & & $S D V$ & 0.01 & 14.67 & 28.14 & 10.00 & 0.6 & 0.00 & 260 & 24.0 & 0.1 \\
\hline \multirow[t]{4}{*}{2008} & Aug & Mean & 1.26 & 11.66 & 0.10 & 47.78 & 12.2 & 0.070 & 4891 & 114.7 & 4.1 \\
\hline & & $S D V$ & 0.04 & 6.99 & 0.14 & 8.33 & 0.4 & 0.01 & 274 & 20.0 & 0.7 \\
\hline & Nov & Mean & 1.25 & 26.23 & 0.10 & 65.56 & 14.4 & 0.063 & 18461 & 157.3 & 2.9 \\
\hline & & $S D V$ & 0.09 & 23.02 & 0.09 & 5.27 & 0.4 & 0.00 & 400 & 12.6 & 0.2 \\
\hline \multirow[t]{4}{*}{2009} & Feb & Mean & 0.79 & 11.47 & 1.37 & 101.11 & 26.1 & 0.069 & 799 & 242.7 & 1.9 \\
\hline & & $S D V$ & 0.20 & 6.42 & 0.57 & 6.01 & 1.1 & 0.01 & 116 & 14.4 & 0.0 \\
\hline & May & Mean & 0.66 & 9.33 & 0.18 & 96.67 & 19.9 & 0.072 & 535 & 232.0 & 2.0 \\
\hline & & $S D V$ & 0.06 & 0.00 & 0.24 & 5.00 & 0.7 & 0.00 & 15 & 12.0 & 0.1 \\
\hline \multirow[t]{4}{*}{ Period } & Min & & 0.1 & $<28$ & 0.03 & 30 & 11.6 & 0.046 & 522 & 72.0 & 0.0 \\
\hline & Max & & 1.0 & 101.0 & 185.0 & 160 & 28.8 & 0.362 & 18890 & 384.0 & 0.1 \\
\hline & Media & & 0.6 & 38.5 & 5.9 & 75 & 19.9 & 0.089 & 5021 & 178.9 & 0.0 \\
\hline & $S D V$ & & 0.2 & 25.4 & 22.8 & 31 & 5.7 & 0.076 & 4679 & 75.2 & 0.0 \\
\hline
\end{tabular}

cells per $\mathrm{ml}$ in a Sedgewick-Rafter gridded chamber.

A Draftsman Plot correlation analysis was performed to determine the environmental variables that would influence the dynamics of the seasonal variation, using Spearman's index for the correlation matrix. A one way ANOSIM analysis was performed to verify the spatial differences with the density matrix non parametric variances between the three points (litoral, center and channel) in the different zones (Nuevo Berlín, Fray Bentos and Las Cañas), and sampling month (time). Bray Curtis similarities were used with log transformed data. Statistical analyses were performed with PRIMER 6 (CLARKE \& GoRLEY 2006).

\section{Results}

\section{Environmental variables}

The average monthly values of different parameters between 2006 and 2009 are showed in Table 1. Surface temperature varied seasonally, between 11.6 and $28.8{ }^{\circ} \mathrm{C}$, the conductivity showed low 


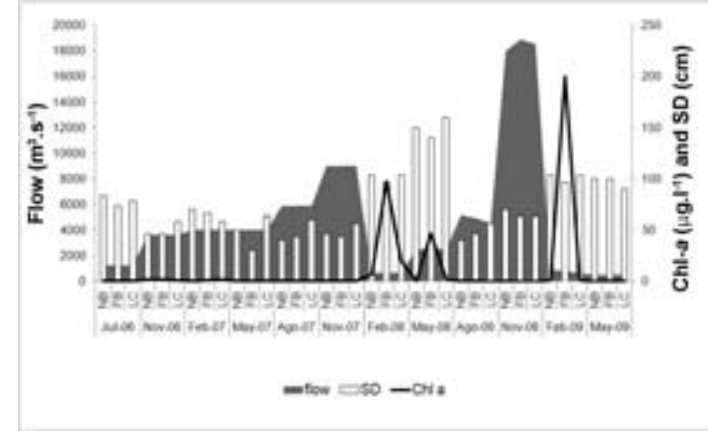

Fig. 2. Relationship between flow, Secchi disk and chlorophyll a, from July 2006 to May 2009 in the three zones: (NB) Nuevo Berlín; (FB) Fray Bentos; (LC) Las Cañas; (Chl-a) chlorophyll-a; (SD) Secchi disk.

variation along the three years (mean value 0.089 $\mathrm{mS} . \mathrm{cm}^{-1}$ ). The phosphate was maximum in the beginning of the studied period $\left(92.4 \mu \mathrm{g} . \mathrm{l}^{-1}\right)$, but then its level decreased to undetectable values. The Redfield equation showed an N:P ratio under 16 , ranging from 2.8 to 34.5 throughout the period, reaching a peak when inorganic nitrogen compounds increased to $1.4 \mathrm{mg} . \mathrm{l}^{-1}$ (average $8.6: 1)$. Chlorophyll showed a peak in the summer of $2008\left(185.0 \mu \mathrm{g} . \mathrm{l}^{-1}\right)$, related to a low flow (2667 $\left.\mathrm{m} . \mathrm{s}^{-1}\right)$. The minimum flow was recorded in the autumn of $2008\left(533 \mathrm{~m}^{3} \cdot \mathrm{s}^{-1}\right)$, while the maximum flow $\left(18,890 \mathrm{~m}^{3} \cdot \mathrm{s}^{-1}\right)$ was observed in November of 2008. Fig. 2 shows the relationship between flow, transparency and chlorophyll $a$, from July 2006 to May 2009 in the three studied sites.

\section{Cyanobacteria composition}

Twenty four cyanobacteria taxa were recorded at the three studied sites. The highest species richness was found in Chroococcales, with 13 taxa, followed by 7 Nostocales and 4 Oscillatoriales. Dolichospermum and Microcystis were the genera with the highest number of species (Table 2). The highest species richness was found in February 2008 (10 species) and no taxa were found during the 2008 winter. Radiocystis fernandoi KoMÁReK et Komarková-Legnerová and Dolichospermum. cf. pseudocompactum (WATANABE) WACKLIN et al. reveals a national record for South America (Figs. 3 - 6). Dolichospermum cf. pseudocompactum presented the trichomes coiled very tightly, with diameters ranging from 7.6-8.3 $\mu \mathrm{m}$, and often coiled in pairs, without any mucilaginous envelopes. Cells were generally spherical or barrel shaped, with 6-8 $\mu \mathrm{m}$ long, spherical heterocytes with $12-\mu \mathrm{m}$ in diameter; one slightly ellipsoidal akinete (length $25 \mu \mathrm{m}$, width $10 \mu \mathrm{m}$ in size) was observed, although most of trichomes appeared without akinetes (Fig. 5 and Fig. 6).

\section{Cyanobacteria abundance}

The phytoplanktonic abundance reported in the monitoring sampling during the whole period of studied were $12.1 \times 10^{3}$ cell. $\mathrm{ml}^{-1}$ in Nuevo Berlín, $4.7 \times 10^{3}$ cell. $\mathrm{ml}^{-1}$ in Fray Bentos and $2.6 \times 10^{3}$ cell. $\mathrm{ml}^{-1}$ in Las Cañas. During summer of 2008 at the Fray Bentos station, a cyanobacteria bloom was reported. Total densities of cyanobacteria of $6.2 \times 10^{6}$ cells. $\mathrm{ml}^{-1}$ were recorded. Microcystis aeruginosa, Microcystis wessenbergii, Dolichospermum circinale and Dolichospermum cf. pseudocompactum were observed during the bloom, where Microcystis aeruginosa and Dolichospermum cf. pseudocompactum reach $5.7 \times 10^{6}$ cells.ml $^{-1}$ and $4.2 \times 10^{5}$ cells.ml ${ }^{-1}$, respectively. In this bloom microcystin-LR were not quantified.

\section{Relationship between cyanobacteria groups and environmental variables}

A Draftsman Plot correlation determined a positive correlation between the density of cyanobacteria and temperature $(\mathrm{r}=0.4)$ as well as with the euphotic zone $(r=0.3)$ and negative with flow $(\mathrm{r}=-0.2)$ all along the studied period. This correlations were higher when the analysis was carried out separately each year (temperature $r=0.8$ and flow $r=-0.7)$. The ANOSIM result between sampling (months) showed a marked seasonality: $\mathrm{R}_{\text {global }}=0.401, \mathrm{p}<0.001$. But it showed no spatial differences between points: $\mathrm{R}_{\text {global }}=-0.014, \mathrm{p}<0.859$ and zones: $\mathrm{R}_{\text {global }}=0.023$, $\mathrm{p}<0.076$. Spring and winter were characterized by cryptophytes, while summer and autumn were characterized by cyanobacteria and diatoms.

Fig. 7 shows the relation between flow changes with euphotic zone, the main nutrients, temperature and pigment (Chla) with the variation in phytoplankton density during August 2006 to May 2009. A negative relationship between flow and euphotic zone is shown. Phosphates and nitrates decreased from 2006 to 2009. Seasonal phytoplanktonic patterns were presented, with maximum density in summer (February 2008), due to the development of the biomass of cyanobacteria.

\section{Discussion}

In this study, water quality in lower Uruguay River was below limit values proposed by the guidance 
Table 2. Presence of cyanobacteria taxa at the three zones at the Lower Uruguay River.

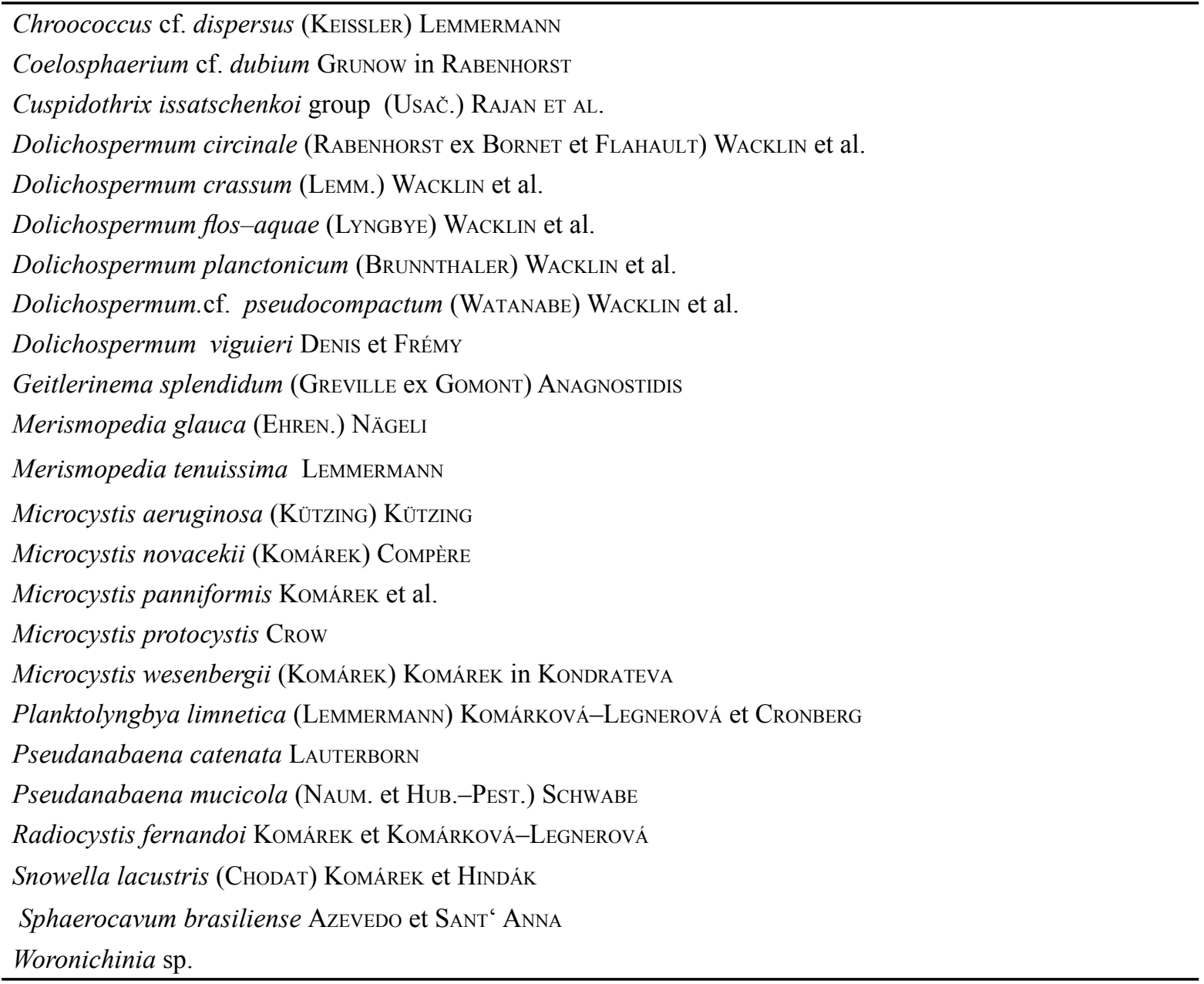

for national legislation according to Digest of Quality by the binational Commission: Comisión Administradora del Río Uruguay (CARU 1988) and by the Decree 253/79 on the Water Code to prevent environmental pollution. An exception was total phosphorus which was above the limit $\left(>25 \mu \mathrm{g} . \mathrm{l}^{-1}\right)$ during the period 2006-2007; after that (2008-2009), values decreased until being undetectable.

Previous studies in the 80 'showed similar results, when nutrient values of phosphate were $<$ $2-14 \mu \mathrm{g} . \mathrm{l}^{-1}$ nitrate $0.8-2.0 \mathrm{mg} . \mathrm{l}^{-1}$ in the region of Salto Grande (Di Persia \& NeIFF 1986; Quirós \& CucH 1981; Quirós \& LuCHINI 1982). Phosphates were 1 - $32 \mu \mathrm{gg} . \mathrm{l}^{-1}$ while total nitrogen values were 3.5-18.9 mg. $1^{-1}$ in the lower Uruguay River (O'FAREll \& IzAGuirre 1994).

Basic stoichiometry (N:P ratio) was evaluated as an indicator of the physiological state of the organisms, showing that the system was not limited by phosphorous (average: 7.1:1). However, in previous studies this ratio was over
14:1 in all running waters studied including the Uruguay River and its tributaries (QuiRós \& LuCHINI 1982; O'FARELl \& IZAGUIRRE 1994).

The number of cyanobacteria species found in our study was in general lower than the results reported by other authors. A previous study in 1986, considering the whole Lower Uruguay River and eight tributaries, reported 54 cyanobacteria taxa (O'FARELL \& IZAGUIRRE 1994). García De Emiliani (1981), Zalocar (2002), ZaLOCAR et al. (2007) and ZaLOCAR \& Forasteir (2007) who studied the northern and subtropical regions, along the Paraná and Paraguay Rivers also found higher cyanobacteria richness $(16,12$ and 49 species respectively).

The nostocacean Dolichospermum cf. pseudocompactum was previously known only from eutrophic lakes in Central Japan (WATANABE et al. 2004, KoMÁreK \& ZAPOMĚLOVÁ 2007) and from Jehay Douves, a small artificial lake in Belgium (Willame \& HofFmanN 1999). D. pseudocompactum Uruguayan population 


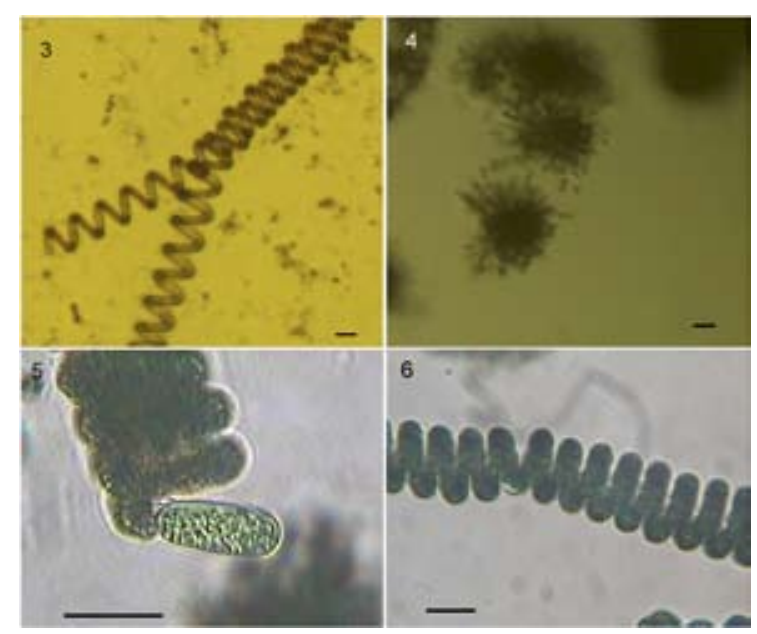

Figs. 3-6. (3) Dolichospermum cf. pseudocompactum general aspect of the filament with regular coiled, one filament twisted inside the other; (4) Radiocystis fernandoi; (5) Dolichospermum cf. pseudocompactum trichoma with one akinete; (6) D. cf. pseudocompactum trichome with one heterocyte. Scale bar $20 \mu \mathrm{m}$.

differs from the Japanese and Belgian ones in the diameter of the trichome coiling and in the akinete, which was bigger in the Uruguayan population (Table 3). From morphological point of view $D$. pseudocompactum is closer to $D$. compactum when akinetes are not present, but $D$. compactum has smaller cell dimensions. Likewise, D. compactum was classified in different clusters according to molecular studies (RAJANIEMI et al. 2005). Molecular analysis of the Uruguayan species is not possible with the currently available data; further research is needed in order to achieve a more complete analysis of the population.

In temperate rivers, the development of phytoplankton is strongly correlated with the concentration of nutrients (BASU \& PICK 1995; DodDs 2006). Coastal morphology, presence of protected areas and low-speed currents are also important factors in phytoplankton development (REYNOLDS 1988). According to REYNolds (2000), hydrological factors such as discharge and dead zones (areas of high resilience) are the most important factors in the development of rivers' phytoplankton. The bottom of the basin, which was object of this study, acts as a natural receptor of the dragged nutrient burden and processes drift; consequently, nutrients would not be a limiting factor for the development of cyanobacteria blooms. Consequently, the dynamics of phytoplankton would be regulated by rains and Salto Grande dam management in the lower Uruguay River.
The flow is the main physical factor in the dynamics of phytoplankton, being the main access of nutrients. According to previous studies in the Salto Grande reservoir and upstream, the main access route of nutrients to the system was also the channel flow of the Uruguay River (BERON 1990; Conde et al. 1996; Chalar et al. 2002). When flow increases, not only do levels of phosphorous increase, but also the basin bottom is removed by increasing turbulence and suspended solids, which in turn, decreases transparency and increases the light extinction coefficient, resulting in decreasing values of phytoplankton density. Cryptomonas were the organisms which turned out to be better adapted to these conditions. The second key factor for growth is temperature. In spring phytoplankton biomass increase with temperature increments, then in summer cyanobacteria becoming dominant. In the Uruguay River, phytoplankton development is limited because of light, not by nutrients. N:P relationship is never limiting for $\mathrm{P}$, as it happens in other aquatic systems. Cyanobacterias blooms in Lower Uruguay River were reported since 1974 (Ono 1978; Ose 1978; Quirós \& Lucchini 1982; Di Persia \& Neiff 1986; Berón 1990; Conde et al. 1996; Chalar et al. 2002). In the summer 2005, a bloom of Microcystis aeruginosa was reported in the study area, reaching 20000-30000 cells. $\mathrm{ml}^{-1}$ (CELA 2006); the levels of microcystin-LR detected in the water at that same time reached $0.79 \mathrm{mg} . \mathrm{l}^{-1}$ in Nuevo Berlín, but its peak was reported in February (1.14 mg. $\left.1^{-1}\right)$ in Fray Bentos (SAIZAR et al. 2010). In these situations, factors such as the nutrient values (soluble phosphorous: $37 \mu \mathrm{g} . \mathrm{l}^{-1}$ and nitrate: $0.57 \mathrm{mg} . \mathrm{l}^{-1}$ in average), high temperature $\left(29^{\circ} \mathrm{C}\right.$ in average) and low flow (less than $1000 \mathrm{~m}^{3} \mathrm{~s}^{-1}$ during summer, promoted the growth of cyanobacteria. Upstream, in the summer of 2008, a bloom of Dolichospermum spiroides was reported in Monte Caseros on the Argentine coast with peak densities reaching $8.8 \times 10^{6}$ cell. $\mathrm{ml}^{-1}$ (OtAÑo \& RomÁn 2008). The mentioned authors consistently described the bloom with the same conditions in low level (max: $2 \mathrm{~m}$ ) and low turbidity (range $25-40$ NTU).

Two possible scenarios could account for the cyanobacteria bloom dynamics in the Lower Uruguay River. One is that in high flow conditions, the bloom is generated in the dam and reaches open water of the Río de la Plata estuary as a result of rainfalls or by the management of the Salto Grande Dam. In low flow conditions (lentic characteristic) the bloom is generated by 
Table 3. Dimensions ( $\mu \mathrm{m}$ ) of Dolichospermum pseudocompactum, comparison between Japanese (WATANABE 1996), Belgian (Willame \& HoffmanN 1999) and Uruguayan populations ( $\mathrm{n}=$ number of measured cells or filaments).

\begin{tabular}{ccccccc}
\hline & \multicolumn{2}{c}{$\begin{array}{c}\text { Lake Teganuma } \\
\text { (Japan) }\end{array}$} & \multicolumn{2}{c}{$\begin{array}{c}\text { Lake Jehay Douves } \\
\text { (Belgium) }\end{array}$} & \multicolumn{2}{c}{$\begin{array}{c}\text { Uruguay River } \\
\text { (Uruguay) }\end{array}$} \\
\cline { 2 - 7 } & Width & Length & Width & Length & Width & Length \\
\hline Vegetative cells & $5.2-7.0$ & $3-6.8$ & $5.4-6.0$ & $5.6-7.2$ & $7.6-8.3$ & $\begin{array}{c}6.0-8.0(\mathrm{n} \\
>100)\end{array}$ \\
Heterocytes & $5.5-7.5$ & & $7.1-7.9$ & & $9-12.0$ & $(\mathrm{n}=5)$ \\
Akinetes & $7.5-11.3$ & $16.8-$ & $6.8-9.0$ & $13-19$ & $10.0-12.6$ & $\begin{array}{c}22.3-25.0 \\
(\mathrm{n}=2) \\
\text { Diameter of trichome coiling }\end{array}$ \\
\hline
\end{tabular}

both: high water column stability and sediment resuspension caused by the wind. In both cases, temperature, nutrient supply and turbidity would be the main factors leading to the development of cyanobacteria.

Inspite oftheheterogeneous geomorphology in the three sampling sites, no significant differences were found in the composition and density of cyanobacteria. That means that the cyanobacteria community showed a similar behavior, favoring the hypothesis, so the bloom could not have been an impact caused by wastes from the pulp mill.

Several authors have modeled the growth and movement of cyanobacteria in river systems (Lung \& Pearl 1988; Maier \& Dandy 1997; Guven \& Howard 2006), establishing that the varying flow conditions play a major role in initiating blooms, with the strong vertical mixing generated by high river flows eliminating conditions favorable for cyanobacteria. MitROVIC et al. (2003) investigated the critical flow velocity in the Darling River (Australia) for an Anabaena circinalis bloom. The bloom was stopped in areas where the turbulent river velocity exceeded a critical value of $0.05 \mathrm{~m} \cdot \mathrm{s}^{-1}$. In the case of the Uruguay River, near Fray Bentos, where the width is $1800 \mathrm{~m}$, we noticed that the critical value could be higher, ranging around $2000 \mathrm{~m} \cdot \mathrm{s}^{-1}$.

Future studies may envisage the application of other models, such as PROTECH-C (ELLIOT et al. 2001), which was developed for lakes, also to include the effect of climate change. "El Niño" events have also had an impact on stream flows in the Rio de la Plata Basin, and we suggest that flow rates of the Uruguay River into the Rio de la Plata drifting the bloom toward the beaches in the capital city, Montevideo, would have a potencial risk impact upon public health (SIENRA

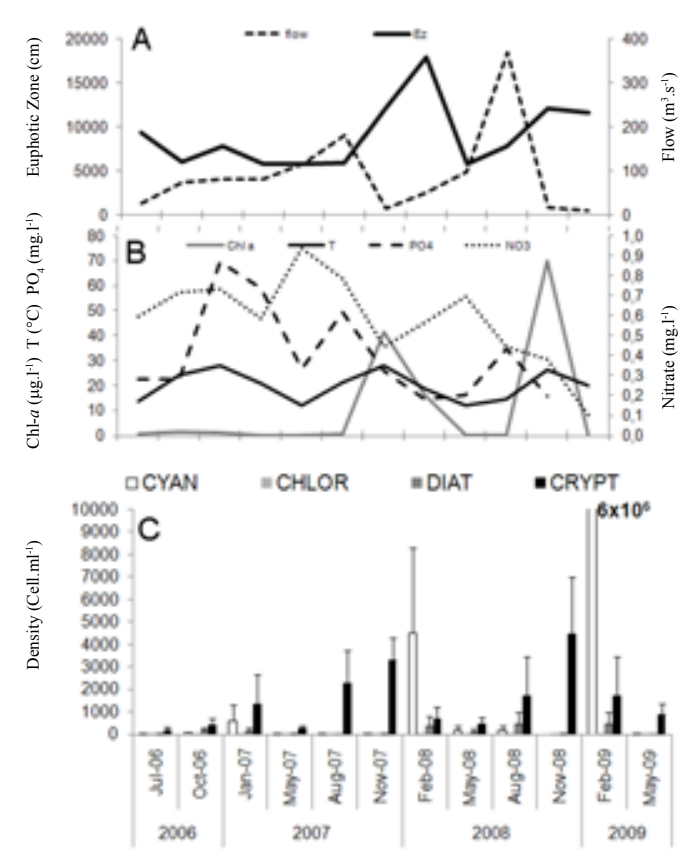

Fig. 7. Average and standard deviation in the three zones in the study area, from July 2006 to May 2009 of: (A) flow $\left(\mathrm{m}^{3} \cdot \mathrm{s}^{-1}\right)$ and euphotic zone $(\mathrm{cm})$; (B) nitrate $\left(\mathrm{NO}_{3} \mathrm{mg} \cdot \mathrm{l}^{-1}\right)$, phosphate $\left(\mu \mathrm{g} .1^{-1}\right)$, temperature $\left({ }^{\circ} \mathrm{C}\right)$ and chlorophyll- $a\left(\mu \mathrm{g} .1^{-1}\right)$; (C) density phytoplankton group (cells. $\mathrm{ml}^{-1}$ ), Cyanophyceae (CYAN), Chlorophyceae (CHLOR), Bacillariophyceae (DIAT) and Cryptophyceae (CRYPT).

\section{\& FERRARI 2006).}

The occurrence of species of the genera Microcystis and Dolichospermum in the Uruguay River should be viewed as a warning, showing the importance of preventing any incidents due to toxins, taste and odor production in the drinking water supplies and recreational waters.

\section{Acknowledgements}

The authors are very grateful to UPM, who permitted the use of the monitoring results for the purpose of 
scientific investigation. We want to thank the technical experts and colleagues M. Bado, G. Useta, P. Morales, J. Clemente and L. Boccardi of the Technological Laboratory of Uruguay (LATU) for their help with the samplings. To Vera Regina Werner and Célia Sant'Anna for their suggestions. To Trinidad Ott and Arianna Masello for English language revision. This study was partly supported by a grant from ANII (National Research and Innovation Agency) and LATU. We wish to express our special thanks to Prof. J. Komárek for his kind assistance during his visit to our lab, and for contributing to the discussions on taxonomy issues and also we want to thanks all reviewers who improve this manuscript.

\section{References}

BAILEY, R. G. (1998): Ecoregions: the ecosystem geography of the oceans and continents. -176 pp. Springer-Verlag, New York.

BAsu, B.K. \& F.R. Pick. (1995): Longitudinal and seasonal development of planktonic chlorophyll $\mathrm{a}$ in the Rideau River, Ontario. - Can J. Fish Aquat. Sci., 52: $804-815$.

Beron, L. E. (1990): Features of the limnological behavoir of Salto Grande's reservoir (Argentina - Uruguay). - Ecol. Model. 52: 87-102.

Bonetto, C. A., Zalocar Y. \& Vallejos, E. (1983): Fitoplancton y producción primaria del Río alto Paraná (Argentina).- Physis 101:81-93.

Bonilla, S., (1997): Composición y abundancia fitoplanctónica de tres embalses en cadena sobre el

Río Negro, Uruguay. - Iheringia Sér. Botanica 49: 47-61.

Box, J.D. (1981): Enumeration of cell concentration in suspection of colonial freshwater microalgae, with particular reference to Microcystis aeruginosa. - Brit. Phycol. J. 16: 153-164.

Carmichael, W.W. (1992): A status report on planktonic cyanobacteria (blue-green algae) and their toxins. - 141 pp., EPA/600/R-92-079, Environmental Monitoring Systems Laboratory, Office of Research and Development, U.S. Environmental Protection Agency, Cincinnati, $\mathrm{OH}$.

Comisión Administradora Del Río Uruguay (CARU), (1988): Digesto sobre Usos del Río Uruguay. 42 pp., Tema E-3: Contaminación.

Centros De Estudios Limnológicos Aplicados (CELA) (2006): Establecimiento de una línea de base de las comunidades de fitoplancton, zooplancton y bentos en el Río Uruguay (desde Nuevo Berlín a Las Cañas), Dpto. - 92 pp., Río Negro-Uruguay.

Clarke, K.R. \& Gorley, R.N. (2006): PRIMER v6: User Manual/Tutorial. - 190 pp., Plymouth
Marine Laboratory, Plymouth.

Clarke, K.R. \& Warwick, R.M. (2001): Change in marine communities: an approach to statistical analysis and interpretation. - 144 pp., Plymouth Marine Laboratory, Plymouth, $2^{\text {nd }}$ Edition.

Conde, D., Pintos, W., Gorga, J., De León, R., Chalar, G. \& Sommaruga, R. (1996): The main forces inducing chemical spatial heterogenity in Salto Grande, a reservoir on the Uruguay River. Arch. Hydrobiol./Large rivers 11: 571-578.

Chalar, G. (2009): The use of phytoplankton patterns of diversity for algal bloom management. Limnologica 39: 200-208.

Chalar, G., De León, L., Brugnoli, E., Clemente, J. \& Paradiso, M. (2002): Antecedentes y nuevos aportes al conocimiento de la estructura y dinámica del Embalse Salto Grande. - In: Fernández-Cirelli, A. \& Chalar, G. (eds): El agua en Sudamérica: de la Limnología a la Gestión en Sudamérica. - pp. 123-142, CYTED Aprovechamiento y Gestión de los Recursos Hídricos. Buenos Aires,.

Chalar, G., De León, L., De León, R., Fabián, D. \& Gorga, J. (1993): Evaluación de la eutrofización del Embalse de Salto Grande. Análisis de las relaciones entre los parámetros físico-químicos y biológicos. Informe Final de la primera etapa. CTM-SG. - 125 pp., Universidad de la República. Facultad de Ciencias-Sección Limnología.

Chorus, I. \& Bartram, J. (eds) (1999): Toxic cyanobacteria in water. A guide to public health consequences, monitoring and management. 416 pp., E \& FN Spon \& WHO.

De León, L. \& Chalar, G. (2003): Abundancia y diversidad del fitoplancton en el embalse de Salto Grande (Argentina - Uruguay). Ciclo estacional y distribución espacial. - Limnetica 22: $103-113$.

Di Persia, D.H. \& Neiff, J.J. (1986): The Uruguay River system. - In: DAvies, B.R. \& WALKeR, K.F.(eds): The Ecology of River System. - pp. 559-621, Dr. Junk Publ., The Netherlands.

DodDs, W.K. (2006): Eutrophication and trophic state in rivers and streams. - Limnol. Oceanogr. 51: 671-680.

ECOMETRIX (2006): Cumulative Impact StudyUruguay Pulp Mill. Ref. 06-1344, 221 pp.

ECOMETRIX (2008): BOTNIA S.A Planta de celulosa Orion de Uruguay. Monitoreo independiente del desempeño según lo solicitado por la Corporación Financiera Internacional. Fase 2: Revisión de desempeño ambiental de los primeros seis meses, $74 \mathrm{p}$.

Elliot, J. A., Reynolds, C. S., \& Irish, A.E. (2001): An investigation of dominance in phytoplankton using the PROTECH model. - Freshwater Biol. 46: 99-108. 
García De Emiliani, M.O. (1981): Fitoplancton de los principales cauces y tributarios del Valle aluvial del Río Paraná: tramo Goya-Diamante. - Red Asoc. Cienc. Nat. Litoral 12: 112-125.

García De Emiliani, M.O. (1990): Phytoplankton ecology of the middle Paraná River. - Acta Limnol. Brazil. III: 391-417.

Gómez, N. \& Bauer, D. E. (1998): Phytoplankton from the Southern Coastal Fringe of the Río de la Plata (Buenos Aires, Argentina). - Hydrobiologia 380: $1-8$.

Guven, B. \& Howard, A. (2006): Modelling the growth and movement of cyanobacteria in river systems. - Sci. Total Environ. 368: 898-908.

IzAguirRe, I. \& VinOCUR, A. (1994): Typology of shallow lakes of the Salado river basin (Argentina), based on phytoplankton communities. Hydrobiologia 277: 49-62.

KomÁreK, J. \& Anagnostidis, K. (1989): Modern approach to the classification system of Cyanophytes 4. Nostocales. - Algological Studies 82: 247-345.

KomÁreK, J. \& AnAgnostidis, A. (1998): Cyanoprokaryota I. Chroococcales. - In: EtTL, H., Gärtner, G., Heynig, H. \& Mollenhauer, D. (eds): Süßwasserflora von Mitteleuropa 19/1. - 548 pp., Gustav Fischer Verlag, Stuttgart - Jena.

KomÁreK, J., \& AnAgnostidis, A. (2005): Cyanoprokaryota II. Oscillatoriales. - In: BÜDEL, B., Krienitz, L., Gärtner, G. \& Schagerl, M. (eds): Süßwasserflora von Mitteleuropa 19/2. - 759 pp., Gustav Fischer Verlag, Stuttgart Jena.

KomÁrek, J. \& KomarkovÁ, J. (2002): Review of the European Microcystis-morphospecies (Cyanoprokaryotes) from nature. - Czech Phycology 2: 1-24.

KomÁreK, J. \& ZApomĚlová, E. (2007): Planktic morphospecies of the cyanobacterial genus Anabaena $=$ subg. Dolichospermum -1 . part: coiled types. - Fottea 7: 1-31.

Lacoste De Diaz, E. N. (1961): Algas de aguas continentales de la Argentina. Fitoplancton de Ibicuy (Entre Ríos). - Darwiniana 12: 191202.

Laboratorio Tecnológico Del Uruguay (Latu) (2007): Estudio de las comunidades de fitoplancton, zooplancton y macrozoobentos en el tramo inferior del Río Uruguay (Nuevo Berlín, Fray Bentos y Las Cañas). - 118 pp., Informe de asesoramiento $\mathrm{N}^{\circ}$ 952512, LATU, Montevideo.

Lund, J.W.G., Kipling, C. \& Le Cren, E.D. (1958): The inverted microscope method of estimating Algal numbers and the statistical basis of estimations by counting. - Hydrobiologia 2: 143-170.

Lung, W.S. \& PeArl, A.E. (1988): Modelling bluegreen algal blooms in the Lower Neuse River.
- Water Research 22: 895-905.

Mitrovic, S.M., Oliver, R.L., Rees, C., Brwling, L.C. \& Buckney, R.T. (2003): Critical flow velocities for the growth and dominance of Anabaena circinalis in some turbid freswater river. - Freshwater Biol. 48:164-174.

MAIER, H.R. \& DANDY, G.C. (1997): Modelling cyanobacteria (blue-green algae) in the River Murray using artificial neural networks. - Math Comput. Simul. 43: 377-386.

O'farrell, I. (1993): Comparative analysis of the phytoplankton of fifteen lowland fluvial systems of the River Plate Basin (Argentina). Hydriobiologia 289: 109-117.

O'farrell, I., Izaguirre, I. \& Vinocur, A. (1996): Phytoplankton ecology of the Lower Paraná River (Argentina). - Large Rivers 11 : 75-89.

O'farrell, I. \& Izaguirre, I. (1994): Phytoplankton ecology and limnology of the Uruguay River Lower Basin (Argentina). - Arch. Hydrobiol. 1/2: 155-179.

OnNA, A. (1978): Estudios fitoplanctónicos en el Río Uruguay y sus relaciones con la calidad de las aguas. $-5^{\circ}$ Congreso Argentino de Saneamiento. Santa Fe, 14-20 de mayo 1978.

OtAÑo, S. \& RomÁn, N. (2008): Floración de cianobacterias sobre la costa del Río Uruguay Verano del 2008. V Taller Internacional sobre Enfoques Regionales para el Desarrollo y Gestión de Embalses en la Cuenca del Plata. Itaipú (Paraguay- Brasil), 11-14 de marzo 2008. - 12 pp., Instituto Argentino de Recursos Hídricos.

OtAÑo, S. (2009): First report of the cyanobacterium Aphanizomenon schindleri (Nostocales, Cyanophyceae) in the Uruguay River, Argentina. - Algological Studies 131: 35-42.

Obras Sanitarias Del Estado (OSE) (1978): Resultados de los análisis de muestras de agua del Río Uruguay (margen uruguaya). Resumen. - 27 pp., Comisión Administradora de Salto Grande, Salto.

Pérez, M.C., Bonilla, S. \& Martinez, G. (1999): Phytoplankton community of a polymictic reservoir, La Plata River Basin, Uruguay. - Rev. Brasil. Biol. 59: 535-541.

PÉrez, M.C. (2002): Fitoplancton del Río Negro, Uruguay. - Limnetica 21: 81-92.

Quirós, R. \& Cuch, S. (1982): Características limnológicas del Embalse de Salto Grande, I. Cambios estacionales de ciertos parámetros físico-químicos. - Ecologia 7: 195-224.

Quirós, R. \& LuchinI, L. (1982): Características limnológicas del embalse de Salto Grande, III: Fitoplancton y su relación con parámetros ambientales. - Rev. Asoc. Cs. Nat. Lit. 13: 4966.

Rajaniemi, P., Hrouzek, P., Kaštovská, K., Willame, 
R., Rantala, A., Hoffmann, L., KomÁrek, J. \& Sivonen, K. (2005): Phylogenetic and morphological evaluation of the genera Anabaena. Aphanizomenon, Trichormus and Nostoc (Nostocales, Cyanobacteria). - Internat. J. Syst. Ecol. Microbiol. 55: 11-26.

ReYNOLDS, C.S. (1988): Potamoplankton: paradigms, paradoxes, prognoses. - In: Round, F.E, (ed.): Algae in the aquatic environment. - pp. 285311, Biopress, Bristol.

REYNOLDS, C.S. (2000): Hydroecology of river plankton: the role of variability in channel flow. - Hydrol. Processes 14: 3119-3132.

Saizar, C., Míguez, D., Dabezies, M. Teixeira De Mello, F., Clemente, J., Ferrari, G., Boccardi, L. \& TANa, J. (2010): Estudios de línea de base para una planta de celulosa en el Río Uruguay. - INNOTEC- LATU, Montevideo.

Schiaffino, M. (1977): Fitoplancton del Río Paraná. I. Sus variaciones en relación al ciclo hidrológico en cauces secundarios de la llanura aluvial. Physis 36: 115-125.

Schiaffino, M. (1981): Campaña limnológica "Keratella I" en el río Paraná medio. Fitoplancton de ambientes lóticos. - Rev. Asoc. Cienc. Nat. Litoral 12: 140-147.

Sienra, D. \& Ferrari, G. (2006): Monitoreo de cianobacterias en la costa de Montevideo. -In: Menafra, R., Rodríguez-Galllego, L., Scarabino, F. \& Conde, D. (eds): Bases para la conservación y el manejo de la costa uruguaya. - pp. 413-419, Vida Silvestre Uruguay.

SmaYda T.J. (1997): What is a bloom? A commentary. - Limno. Ocenog. 42: 1132-1136.

SourniA, A. (1978): Phytoplankton manual. Monographs on oceanographic methodology 6 . UNESCO, Paris.

UtermöHL, H. (1958): Zur Vervollkommnung der quantitativen Phytoplankton Methodik. - Mitt. Int. Verein. Limnol. 9: 1-38.

Wacklin, P., Hoffmann, L. \& KomÁreK, J. (2009): Nomenclatural validation of the genetically revised cyanobacterial genus Dolichospermum (Ralfs ex Bornet et Flahault) comb. nova. Fottea 9: 59-64.

Watanabe, M. \& Chinara, M. (1980): Algal flora in Tsukuba Academic New Town. V. Planktonic blue-green algae. - Environ. Res. 5A: 80-86.

Watanabe, M. (1996): Studies on planktonic bluegreen algae 7. Anabaena pseudocompacta sp. nov. from eutrophic lakes in Central Japan. Bull. Nat. Sci. Mus., Ser. B, 22: 93-97.

Watanabe, M., NiIyama, Y. \& Tuji, A. (2004): Studies of planktonic blue-green algae 10. Classification of planktonic Anabaena with coiled trichomes maintained in the National Sciences Museum, Tokyo. - Bull. Nat. Sci. Mus., Ser. B, 30: 135149.
Willame, R. \& HoffmanN, L. (1999): Bloom-forming blue-green algae in Belgium and Luxembourg. - Algological Studies 94: 365-376.

Zalocar De Domitrovic, Y. (2005): Biodiversidad del fitoplancton en el eje fluvial Paraguay - Paraná. - INSUGEO, Miscelánea, Tucumán, 14: 229242.

Zalocar De Domitrovic, Y., Poi De Neiff, A.S.G. \& CAsco, S. L. (2007): Abundance and diversity of phytoplankton in the Paraná River (Argentina) $200 \mathrm{Km}$ downstream of the Yacyretá reservoir. - Braz. J. Biol. 67: 53-63.

Zalocar De Domitrovic, Y., Devercelli, M. \& García De Emiliani, M.O. (2007): Phytoplankton. In: Iriondo, M., Paggi, J.C. \& Parma J. (eds): The middle Paraná River. Limnology of a subtropical wetland. - pp. 175-203, SpringerVerlag, Berlin.

Zalocar De Domitrovic, Y. \& Forastier, M. (2007): Historia de las floraciones del río Paraná en el tramo argentino. - In: Feyen, J., Aguirre, L.F. \& Moraes M.R. (eds): Congreso Internacional sobre Desarrollo, Medio Ambiente y Recursos Naturales: Sostenibilidad a múltiples niveles y escalas. - pp. 1291-1298, Publicación de la Universidad Mayor de San Simón, Cochabamba, Bolivia.

Zalocar De Domitrovic, Y. \& Forastier, M. (2005): Biodiversidad de Cyanophyceae (Cyanobacteria) y especies toxigénicas del litoral fluvial argentino. - In: AcEÑOLAZA, F.G. (ed.): Temas de la Biodiversidad del Litoral Fluvial Argentino II. - pp. 213-228, Insugeo, Miscelánea.

(C) Czech Phycological Society (2011)

Recieved Sept 2010

Accepted Dec 2010 